\title{
Determinants of unemployment in less developed countries
}

\author{
Asma Riaz ${ }^{1, *}$, and Fareeha Zafar $^{2}$ \\ ${ }^{1}$ M.Phill Scholar, School of Management sciences, National college of business and e-Commerce, \\ DHA Campus, Lahore, Pakistan \\ ${ }^{2}$ University Of Derby, United Kingdom
}

\begin{abstract}
Unemployment is a major issue all over the world in both developed and under developed countries. This study analyzes those factors which determine unemployment in Pakistan. The data is taken from1990-2015 to see the empirical relationship between GDP, Population, Technical \& Vocational education, degree colleges and universities enrollment. ARDL (Auto Regressive Distributed Lag) approach is used to check the determinants of unemployment in Pakistan. Long run results show that there is a negative relationship between GDP and unemployment. Population has positive and significant relation and technical \& vocational education has positive and insignificant relation with unemployment in Pakistan. The results of Short run ECM-1(Error correction model) show that the negative and significant relationship with unemployment. The CUSUM and CUSUMQ (Graph) are represent that model is structurally stable within critical bound at 5\% level of significance.
\end{abstract}

Keywords: Unemployment (UNE), Gross Domestic Product (GDP), Population (POP), Technical and Vocational Education (T\&V), Degree colleges enrollment 16 years of qualification (Degr coll), Universities enrollment 16 years of qualification(UNI ENR)

\section{Introduction}

Unemployment is the major problem of every country. Unemployment is an ever rising in Pakistan as determined by Ahmed at.al [1]. The variables are used in this paper, Population growth rate, inflation rate, Foreign Direct Investment and Gross Domestic Product growth rate in framework of Pakistan economy. also. The time series data from 1973 to 2010 was taken to analyze using the ARDL test. The results show that unemployment has significant positive relationship with output gap, Productivity and Economic Uncertainty while it has statistically significant negative relationships with Gross Fixed Investment and Trade . The data was taken from Hand Book of State Bank of Pakistan 2010, This study applies augmented dicky fuller and Philips perron Unit Root tests to confirm the stationary of the

*Corresponding author: asmariaz316@gmail.com 
data series. The results show that in the long run or short run there is positive relationship between unemployment and the output gap.

Muhammad Arslan et al., [8] This paper describe that unemployment is the common factor in all over the world. The variables are used in this paper, Population growth rate, inflation rate, Foreign Direct Investment and Gross Domestic Product growth rate in framework of Pakistan economy. In this foreign direct investment, gross domestic product rate, CPI based inflation rate and population growth rate is taken as explanatory variables. The methodology used in this paper is Ordinary Least Square Model. According to the results of our foreign direct investment, gross domestic product rate and CPI based inflation rate there is there is negative relationship on unemployment between the variables. And there is positive relation between unemployment and Population growth rate. The dependent variable is unemployment and independent variables are foreign direct investment, Gross domestic product growth rate, Inflation rate. According to results FDI has inversely relationship with unemployment.

Muhammad Shafiur Rehman et al. [2] unemployment is the crucial issue in all the countries. Economic growth is also an important factor for unemployment. The data is taken from 2000-2011 and Simple Single Equation Linear Regression Model is used for this paper. The variables are used for this study are Unemployment rate, GDP growth rate, Exchange rate and Inflation rate. The result of Simple Regression Model shows that all variables are significant. Inflation rate positively impact on unemployment and while GDP growth rate and Exchange rate has negatively affected on unemployment.

Dr Aurangzeb et al. [3] examined the economic study of unemployment used for India, China and Pakistan. Data was collected from year for the period 1980 to 2009. The methodology was used integration, granger causality and regression analysis. The variables select for the study are unemployment, inflation, gross domestic product, exchange rate and the increasing rate of population. The result shows the significant impact on three countries. GDP of Pakistan represent the positive relation with unemployment. The granger causality not exists in any variable in all of three countries. Co integration results shows that long term relationship exist between the variables for all the countries.

The meaning of the unemployment is people want to do work but they have not many opportunity. One of the main causes is Population. Approximately the total population of the Pakistan is 195,194,877 [11] Pakistan population ranked no 6 in the world. And now the population literacy rate is $60 \%$ while in $201458 \%$ ( survey 2015).another most important key factor is technical education. Now a day's people not got technical education and the reason is that they have not good job. Our nation does not neglect educated persons. Our youth graduate can change our nation. Government should introduce new training centers and technical education or entrepreneurship which is much benefitted for our society. There are many factors which determine the unemployment in less develop countries but here we use these variables are GDP, population, crude activity rate, employment labor force, industrialization, technical education.

According to (Pakistan Higher Education Commission 2013-2014) 3 million students enrolled in graduates 13, through in Pakistan 1,086 degree colleges and 161 universities. Pakistan qualified age group from 18 to 24 years 3 million people enrolled is $15 \%$ of 20 million. In technical and vocational institutes 255,000 Pakistani students are enrolled (TEVTA).In Pakistan we need 1 million skilled people for industry whereas only 100,000 skilled people are obtainable.90\% labor are unskilled. Over half a million graduates are producing in Pakistani universities. Graduates universities are increased now in our country 380,773 in 2005-2006 to 493,993 in 2008-2009. In the (2003-2008) 400,000 student are enrolled in universities. Now in 2014, the number of universities is 161 and 1.5 million students are enrolled. 
34 million people are unemployed in all around the world. According to the Labor Force Survey 2013-14, the total labor force is 60.09 million in the country. Out of this, 3.58 million people are unemployed and 56.52 million people are employed. [4,5] "According to IPR's factsheet, 2012-13 and 2014-15 the number of jobs created was 1.4 million. Accordingly, the decrease in the number of unemployed workers was 100,000. As such, by the end of 2014-15, the number of unemployed workers was 3.6 million. However, the total number of unemployed currently in Pakistan 5.3 million" The latest Labor Force Survey of 2014-15 released by the Pakistan Bureau of Statistics [10].

\section{Data and methodology}

In the determinants of unemployment we take the data from Economic Survey of Pakistan [2,4,5,6,7] and from "The World Bank" [12]. Data is collected from 1990 to 2015. The dependent variable is unemployment and the Independent variable is GDP, Population, Technical \& Vocational Education and Universities enrollment.

For this purpose we use Econometrics model

Unemployment=f (GDP, POP, T \& V, DEG COLL, UNI NUM).

$G D P=$ All finale goods and services produce in the market in a given year. There is inverse relationship between GDP and unemployment.

$P O P=$ the number of persons are in a country called population. And if the population are increased then unemployment also raise. Population data in million.

$T \& V=$ technical and vocational data in thousands.

$D E G C O L L=$ no of enrollment in degree colleges data 16 years of qualification (In numbers).

$U N I=$ universities enrollment data in numbers (16 years of qualification

\subsection{Model}

$$
\begin{aligned}
\Delta U N E_{\mathrm{t}}=a_{0}+ & \sum_{j=1}^{n} \alpha_{j} \Delta G D P_{t-j}+\sum_{j=1}^{n} \mu_{j} P O P_{t-j}+\sum_{j=1}^{n} \delta_{j} T \& V_{t-j}+\sum_{j=1}^{n} \theta_{j} D_{e g} \operatorname{coll}_{t-j} \\
& +\sum_{j=1}^{n} \pi_{j} U N I t-j+d_{1} G D P_{t-j}+d_{2} P O P_{t-j}+d_{3} T \& V_{t-j} \\
& +d_{4} D e g \operatorname{coll}_{t-j}+d_{5} U N I_{t-j}+\epsilon_{\mathrm{t}}
\end{aligned}
$$

In the model of the paper where unemployment is the dependent variable and GDP, Population, Technical and Vocational education, Degree college's enrollment and Universities enrollment are independent variables.

\section{Findings}

Table 1. Augmented Dicky-Fuller (ADF) test of stationarity of time series data

\begin{tabular}{|l|l|l|l|l|l|}
\hline NO & Description & Variables & Lags & T-statistics & P-value \\
\hline $\mathbf{1 .}$ & Unemployment & Une & $\mathrm{I}(0)$ & -3.561 & 0.0066 \\
\hline $\mathbf{2 .}$ & Gross Domestic Products & GDP & $\mathrm{I}(0)$ & -3.452 & 0.0093 \\
\hline $\mathbf{3 .}$ & Population & POP & $\mathrm{I}(1)$ & -4.328 & 0.0004 \\
\hline $\mathbf{4 .}$ & $\begin{array}{l}\text { Technical \& Vocational Education(16 } \\
\text { years) }\end{array}$ & T\&V & $\mathrm{I}(1)$ & -4.353 & 0.0004 \\
\hline $\mathbf{5 .}$ & Degree Colleges Enrollment & Deg Coll & $\mathrm{I}(1)$ & -4.172 & 0.0007 \\
\hline $\mathbf{6 .}$ & Universities Enrollment(16 years) & Uni Enr & $\mathrm{I}(1)$ & -9.022 & 0.0000 \\
\hline
\end{tabular}


In the Table 1 Augmented Dicky Fuller test are apply to see the stationarity of all the variables

Table 2. Autoregressive Distributed Lag Estimates ARDL $(1,0,0,0,0,0)$ selected based on Schwarz Bayesian Criterion

\begin{tabular}{|c|c|c|c|}
\hline Regressor & Coefficient & Standard Error & T-Ratio[prob] \\
\hline Une(-1) & .66252 & .21785 & $3.0412[.007]$ \\
\hline GDP & -.062933 & .034892 & $-1.8036[.087]$ \\
\hline POP & .011976 & .010173 & $1.1772[.254]$ \\
\hline T\&V & .0013848 & .0022128 & $.62584[.539]$ \\
\hline DEG & $.3037 \mathrm{E}-5$ & $.1301 \mathrm{E}-5$ & $2.3341[.031]$ \\
\hline UNI & $-.1458 \mathrm{E}-5$ & $.6191 \mathrm{E}-6$ & $-2.3546[.029]$ \\
\hline
\end{tabular}

$\mathrm{R}$-squared $=.11252, \mathrm{R}-$ Bar-Squard $=-.12103, \mathrm{~F}$-statistics $=(5,19) .48178[.785]$

Akaik Info Criterion=-5.5035 Schwarz Bayesian Criterion=-9.1601

DW-statistics $=1.4987$

Diagnostic Tests:

Test statistics

LM Version

A: Serial Correlation

CHSQ $(1)=.0024595[.960]$

F Version

B: Functional Form

CHSQ (1) $=9.3193[.002]$

$\mathrm{F}(1,18)=.0017710[.967]$

C: Normality

CHSQ (2) $=17.1100[.000]$

$\mathrm{F}(1,18)=10.6977[.004]$

D: Hetroscedasticity

CHSQ (1) $=5.3955[.020]$

Not applicable

$\mathrm{F}(1,23)=6.3300[.019]$

Table 3. Estimated Long Run Coefficients using the ARDL approach ARDL $(1,0,0,0,0,0)$ selected based on Schwarz Bayesian Criterion

\begin{tabular}{|c|c|c|c|}
\hline \multicolumn{5}{|c|}{ Dependent Variable is GDP } \\
\hline Variables & Coefficient & Standard Error & Ratio (Prob) \\
\hline GDP & -.18648 & .17782 & $-1.0487[.307]$ \\
\hline POP & .035486 & .010395 & $3.4137[.003]$ \\
\hline T\&V & .0041035 & .0079529 & $.51597[.612]$ \\
\hline DEG COLL & $.8999 \mathrm{E}-5$ & $.5566 \mathrm{E}-5$ & $1.6168[.122]$ \\
\hline UNI ENR & $-.4319 \mathrm{E}-5$ & $.2204 \mathrm{E}-5$ & $-1.9601[.065]$ \\
\hline
\end{tabular}

In the Table 3 estimated long run coefficients GDP has negative and insignificant relation with unemployment while population has positive and significant relationship with unemployment, Technical and vocational education and degree colleges has positive and insignificant relation with unemployment.

Table 4. Error Correction Representation for the selected ARDL model ARDL $(1,0,0,0,0,0)$ selected based on Schwarz Bayesian Criterion

\begin{tabular}{|l|l|l|l|}
\hline Regressor & Coefficient & Standard Error & T-Ratio[prob] \\
\hline Dgdp & .062933 & .034892 & $-1.8036[.087]$ \\
\hline Dpop & .011976 & .010173 & $1.1772[.254]$ \\
\hline Dt & .0013848 & .0022128 & $.62584[.539]$ \\
\hline Ddegre & $.3037 \mathrm{E}-5$ & $.1301 \mathrm{E}-5$ & $2.3341[.031]$ \\
\hline Duni & $-.1458 \mathrm{E}-5$ & $.6191 \mathrm{E}-6$ & $-2.3546[.029]$ \\
\hline Ecm $(-1)$ & -.33748 & .21785 & $-1.5492[.000]$ \\
\hline
\end{tabular}

R-Squared=.30441, R-Bar Squared $=.12137, \mathrm{~F}$ Stat. $\mathrm{F}(5,19)=1.6630[.192]$

Akaike Info. Criterion=-5.5035 Schwarz Bayesian Criterion=-9.1601

In the Table 4 According to the short run results coefficient of gdp, population, technical and vocational education and universities enrollment are $.062933, .011976$ and 0013848. The short run coefficient is smaller than long run. ECM (-1) is one period lag value of error term that is come from long run relationship. ECM values represent that the disequilibrium of short run will be fixes long time period. 
CUSUM and CUSUMQ sum of squares Graphs

Plot of Cumulative Sum of Recursive Residuals

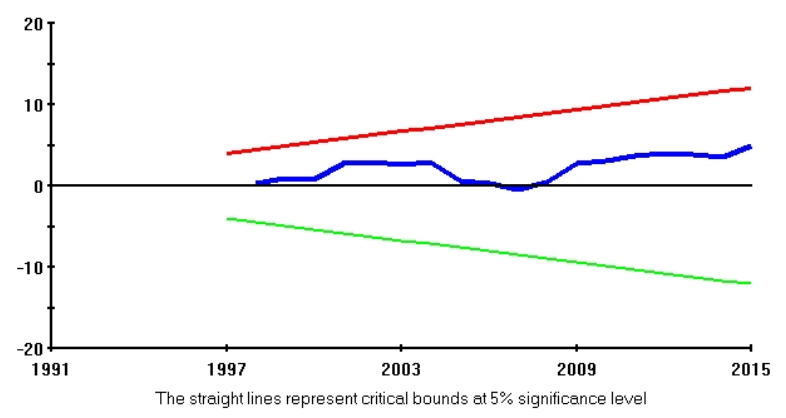

Figure 1.

In CUSUM chart the lines are not crossing each other means that there is no issue of recursive residuals in terms of mean. Similarly, there is no issue of recursive residuals in terms of variance.

Plot of Cumulative Sum of Squares of Recursive Residuals

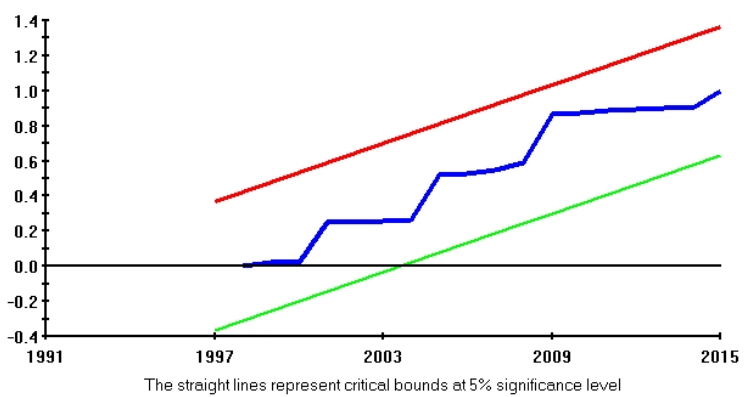

Figure 2.

Figure 1 and 2 represent that cumulative sum of recursive residuals the cumulative sum of square of recursive residuals. Both CUSUM and CUSUMSQ are within critical bound of $5 \%$ so this shows that model is structurally stable.

\section{Conclusion}

The impact of GDP, Population, Technical \& Vocational education, Degree college's enrollment and universities was examined on the unemployment rate of Pakistan and the period is 1990-2015. We have used ARDL

(Auto Regressive Distributive Lag) test on it. The Long Run results have shown that there is negative relation between GDP and unemployment. Population has positive relation with unemployment while Technical \& Vocational education has positive effects on unemployment. Short Run results explain that Population, Technical and Vocational Education have positive effects. ECM (-1) represents the lag value one period of error term that come from long run relation. ECM (-1) represent disequilibrium of short run. ECM (-1) has statistically significant and negative value. The main focus of our study shows that our 
education or technical and vocational education system may control the determinants of unemployment in Pakistan.

This study is helpful for the policy makers which are trying to control unemployment in Pakistan. Government should increase the numbers of tech $n$ vocational institutes. These institutions can play a vital role to decrease the unemployment in Pakistan.

\section{References}

1. Ahmed Raza Cheema, A. A. Economic Determinants of unemployments in Pakistan. International Journal of Business and Social Science, 5 (3), (2014).

2. Chowdhury, M. S., \& Hossain, T. M. Determinants of Unemploment in Bangladesh:A case study. Developing Country Studies , 4, (2014).

3. Dr Aurangzeb, k. A. Facyor Effecting Unemployment:A cross Country Analysis. International Journal of Academic Research Business and Social Science, 3 (1). (2013).

4. Economic survey. Retrieved from IPR's factsheet. (2012-13 and 2014-15).

5. Economic survey of Pakistan. (2013-2014).

6. Government of Pakistan Ministry of Finance. Retrieved from Ministry of finance: www.finance.gov.pk (1990-2015).

7. Government of Pakistan ministry of finance. Retrieved from Pakistan economic survey: www.finance.gov.pk (2014-2015).

8. Muhammad Arslan, R. Z. Unemployment and Its Determinants:A Study of Pakistan. Journal of Economics and Sustainable Development , 5 (13).

9. PakAlumni World wide. (n.d.). Retrieved from Pakalumni: www.pakalumni.com

10. Pakistan Bureau of Statistics government of Pakistan. (2015-2016). Retrieved from Pakistan Bureau of Statistics: www.pbs.gov.pk

11. Pakistan world meter. (2017). Retrieved from worldmeters: www.worldmeters.info.pk

12. The World Bank. (1990-2015). Retrieved from World Bank: www.data.worldbank.org 